ISSN 0258-7122

Bangladesh J. Agril. Res. 38(1): 77-84, March 2013

\title{
VARIABILITY AND CHARACTER ASSOCIATION IN BANGLADHONIA (Eryngium foetidum L.)
}

\author{
S. N. MOZUMDER ${ }^{1}$, M. M. RAHAMAN ${ }^{2}$ AND M. M. HOSSAIN ${ }^{2}$
}

\begin{abstract}
The experiment was conducted at the Horticulture Field Laboratory of Bangabandhu Sheikh Mujibur Rahman Agricultural University, Gazipur during November 2005 to July 2006. Twelve genotypes of Bangladhonia (E. foetidum L.) were collected from different parts of Bangladesh and evaluated them to analyze the variations. Most of the yield attributing characters and individual plant performances exhibited insignificant differences among the genotypes. All the genotype had the similar plant and leaf size, number of leaves/plant, weight of leaves/plant, flowering behavior, yields and other qualitative characters. Greater positive correlation was observed between plant populations with yield performances. The symmetric performance indicted that all the genotype belongs from the same species of E. foetidum L. and there was no major phenotypic or genotypic variation among them.
\end{abstract}

Keywords: Bangladhonia, genotype, multivariate, analysis, performance.

\section{Introduction}

Bangladhonia (Eryngium foetidium L.), a tropical biennial herb belongs to the family Apiaceae. It is native to Mexico and South America or continental tropical America and the West Indies (Adams, 1971), but cultivated worldwide. It is also grown and used extensively in Thailand, India, Vietnam, Bangladesh and other parts of Asia as a culinary herb. (Nienga, 1995, Rashid, 1999, Rubatzky et al., 1999). About 228 species of Eryngium are reported worldwide (Lawrence, 1967). Among them, Eryngium foetidum L. is domesticated, widely cultivated and exported to others countries for consumption as culinary herb as well as medicinal use. Its cultivation and popularity in several parts of the world are increasing due to its attractive strong aroma, medicinal and nutritional values, versatile use and wide adaptability with temperature, soil condition and water stress. In Bangladesh, one species of Eryngium (E. foetidum L) known as Bangladhonia or Bilatidhonia, is found more or less in most of parts of the country. It is more concentrated and commercially cultivated in the Chittagong Hill tracts, especially in Kaptai Upazilla of Rangamati Hilly District. In an on farm investigation on cultivation of Bangladhonia some morphological variation was observed in the plants of different places (Mozumder, 2003). Analysis is required to find out whether the variation is due to environmental or there is any

${ }^{1}$ Senior Scientific Officer, Research Wing, Bangladesh Agricultural Research Institute (BARI), Gazipur-1701, ²Professor, Department of Horticulture, Bangabandhu Sheikh Mujibur Rahman Agricultural University, Salna, Gazipur-170, Bangladesh. 
genetic variation. Before commenting about the variation of the crop, it is necessary to cultivate these genotypes in the same field giving same input facilities. However, the study was undertaken to collect the genotype from different places of Bangladesh and to evaluate them in the field under similar condition and analyze the useful characters.

\section{Materials and Method}

The experiment was conducted at the Horticulture Field Laboratory of Bangabandhu Sheikh Mujibur Rahman Agricultural University, Gazipur during November 2005 to July 2006. The location of the experimental site was on $24^{\circ} 09^{\prime}$ North latitude and $90^{\circ} 26^{\prime}$ E longitude with an elevation of $8.50 \mathrm{~m}$ from the sea level (Anon., 1989). The experimental field belongs to the 'Shallow red brown terrace' soil of Salna series under Madhupur tract of AEZ -28. The $\mathrm{pH}$ of the experimental soil was 5.9. The experiment was laid out in a randomized complete block (RCB) design having twelve Treatment (12 accessions) with three replications. The unit plot size was $3 \mathrm{~m} \times 1 \mathrm{~m}$. Twelve genotypes were collected from Rangamati, Bandarban and Khagrachari districts and one was collected from Gazipur. The places of seed collections are presented in the Table 1.

Table 1. Sources and location of collected Bangladhonia genotype.

\begin{tabular}{c|c|l}
\hline Serial no. & Accession number & \multicolumn{1}{c}{ Location of seed collection } \\
\hline 1 & BD001 & Murali, Wagga, Kaptai, Rangamati \\
2 & BD002 & Satparpara, Thanchi, Bandarban \\
3 & BD003 & Thanchi Bazar, Bandarban \\
4 & BD004 & Wangantam Para, Kaptai, Rangamati \\
5 & BD005 & Thanchui Para, Bandarban \\
6 & BD006 & Thanchui Para, Bandarban \\
7 & BD007 & Rikhai Para, Bandarban \\
8 & BD008 & Saungathong Para, Thanchi, Bandarban \\
9 & BD009 & Rialidong Para, Thanchi, Bandarban \\
10 & BD010 & Sapchhari, Manikchhari, Khargachhari \\
11 & BD011 & Doluchhari, Bandarban Sadar, Bandarban \\
12 & BD012 & Faokal, Gazipur \\
\hline
\end{tabular}

The land was carefully prepared by ploughing and cross ploughing followed by laddering because Bangladhonia seeds are very small and responsive to the physical condition of the beds (Moniruzzaman, 2000). Manures and fertilizers were applied @ Cowdung 15 tons, urea 350 kg, TSP 150 kg, and MoP 200 kg per hectare. The entire amount of cowdung and TSP with one fourth of urea and 
MoP were applied during final land preparation. The rest of the urea and MoP were applied in three equal installments at 45, 75 and 105 days after sowing of seeds (Islam et al., 2003). Seeds of 12 Bangladhonia genotypes were sown @ 40 $\mathrm{kg} / \mathrm{ha}$ ((12 g/plot) by broadcasting on 08 December 2005. After sowing the plots were covered with dry rice straw to make the soil uniformly moist for better germination. After sowing, black mosquito (nylon) nets (2 mm loop) was hanged at 1.5 meter height over the experimental plots to maintain approximately $50 \%$ photosynthetically active radiation (PAR), with the help of GI wire and bamboo poles in order to ensure soft, lengthy and succulent leaves (Moniruzzaman, 2006). Straw mulch was removed when germination started and weeding was done carefully. Weeding was done, frequently after germination. Sprinkler irrigation was given twice in a week and flood irrigation was given to the plants after each top dressing of urea and MoP. Thinning was done at the time of harvest when longer (leaf) plants were picked up for marketing. A number of flower stalks were produced and it was counted and broken so that more leaves could be produced. For the control of damping off and leaf blight, Ridomil gold $(0.2 \%)$ was sprayed three times at 10 days interval. As there was no insect pest, no insecticide was applied. Harvesting was done from May 25 to July 25 with an interval of 20 days when the leaves became most succulent. Data recorded on days to seed emergence, seedlings population $/ \mathrm{m}^{2}$, plant height, leaves per plant, length of leaf $(\mathrm{cm})$, width of leaf $(\mathrm{cm})$, fresh plant weight, days to flower stalk emergence, harvested plants $/ \mathrm{m}^{2}$, thousand seed weight, days to first flowering, flower stalk number. The percentage of flowering and dry matter percentage was calculated using the following formula:

Percentage of flower stalk $=\frac{\text { Number of flower stalk } / \mathrm{m}^{2}}{\text { Number of plants } / \mathrm{m}^{2}} \times 100$

Dry matter percentage $=\frac{\text { Dry weight of plants }}{\text { Fresh weight of plants }} \times 100$

Qualitative and morphological data on leaf, stem, root and flower stalk were recorded according to botanical descriptors (Bandre and Pande, 1999). All the data were compiled properly and analyzed statistically using MS-Excel and SPSS Program. Descriptive analysis and Hierarchical cluster analysis using different yield attributing and other characters were conducted using SPSS and Genstat program, respectively.

\section{Results and Discussion}

Performances of 12 Bangladhonia genotypes are presented in Table 2, 3, and Fig. 1. All parameters except seedlings $/ \mathrm{m}^{2}$ and harvested plants $/ \mathrm{m}^{2}$, leaves/plant, flowering percentage and marketable yield (t/ha) exhibited insignificant corelational interference among the genotype. 


\section{Descriptive statistics of 12 Bangladhonia genotypes}

Descriptive statistics of collected 12 Bangladhonia geenotypes are presented in Table 2. This result represents the minimum, maximum, mean and standard deviation of parameters studied. The average germination period of 12 genotypes was 17.25 days with 0.4421 standard deviation. Seedlings $/ \mathrm{m}^{2}$ ranged from 183 to 894 with a mean of 682. The standard deviation of 206.01 is higher than the lowest value that indicated a greater variation in number of seedlings $/ \mathrm{m}^{2}$ between genotype.

A lower standard deviation (1.386) compared to mean value (113.54 days) in days to flowering indicated the synchronized flowering among the genotypes. This is also a symmetric behavior of all genotype that might lie in the same group or cluster. The mean value of plant height, single plant weight, leaves/plant, leaf length and leaf width were $26.43 \mathrm{~cm}, 6.27 \mathrm{~g}, 5.85,18.79 \mathrm{~cm}$ and $2.18 \mathrm{~cm}$ having lower standard deviation valued $0.38,0.124,0.09,0.247$ and 0.085 , respectively, indicated the minimum morphological and genetic variations among the genotype. Lower standard deviation and insignificant variation proves that all the genotype had the same genetic make up. These findings agreed with the comments of Rashid (1999) who studied probably only one species (E. foetidum) cultivated in Bangladesh.

Table 2. Variabilities in 14 traits of 12 germplasm of Bangladhonia.

\begin{tabular}{l|c|c|c|c|c}
\hline \multicolumn{1}{c|}{ Variables } & $\begin{array}{c}\text { No. of } \\
\text { accession }\end{array}$ & Minimum & Maximum & Mean & $\begin{array}{c}\text { Standard } \\
\text { deviation }\end{array}$ \\
\hline Days to germination & 12 & 16.30 & 17.70 & 17.25 & 0.442 \\
Seedlings $/ \mathrm{m}^{2}$ & 12 & 183.00 & 894.00 & 681.67 & 206.010 \\
Days to flowering & 12 & 110.30 & 115.70 & 113.54 & 1.386 \\
Plant height (cm) & 12 & 25.70 & 27.20 & 26.43 & 0.380 \\
Plant weight (g) & 12 & 6.13 & 6.58 & 6.27 & 0.124 \\
Leaves /plant & 12 & 5.67 & 6.00 & 5.85 & 0.090 \\
Leaf length (cm) & 12 & 18.40 & 19.20 & 18.79 & 0.247 \\
Leaf width (cm) & 12 & 2.06 & 2.36 & 2.18 & 0.085 \\
Flower stalks & 12 & 46.70 & 63.70 & 54.34 & 4.698 \\
Flowering percentage & 12 & 9.80 & 29.94 & 14.19 & 5.501 \\
Flower stalk weight g/m ${ }^{2}$ & 12 & 138.00 & 156.70 & 146.20 & 5.300 \\
Harvested plants/m ${ }^{2}$ & 12 & 156.00 & 525.00 & 417.92 & 103.438 \\
Marketable yield (t/ha) & 12 & 10.26 & 32.61 & 26.10 & 6.191 \\
Dry matter percentage & 12 & 14.69 & 15.53 & 14.98 & 0.261 \\
\hline
\end{tabular}

The mean flower stalks, percentage of flowering and weight of flower stalks was $54.34 / \mathrm{m}^{2}, 14.19$, and $146.2 \mathrm{~g} / \mathrm{m}^{2}$ with moderate standard deviation of 4.698 , 5.501 and 5.3 indicated moderate variations of genotype in respect to these 
characters. These characters might be influenced by number of plants which had a much variation in the present investigation. The number of plants per unit area ranged from 156 to 525 with an average of 417.92 and standard deviation 103.438. This high variation might be due to the germination variation of seeds that was collected from different farmers, places and markets in different dates. The marketable yields ranged from 10.61 to 32.61t/ha with 26.10 mean having 6.191 standard deviation.

The dry matter percentage ranged from 14.69 to 15.53 , mean 14.98 and standard deviation was 0.261 . The fresh marketable yield variation was mainly due to the variation of number of plants per unit area.

\section{Correlation among 14 characters of 12 Bangladhonia genotype}

The 2-tailed Pearson correlation co-efficient values and level of significance among 14 yield attributing and other characters of 12 Bangladhonia genotype are presented in Table 3. There was a moderate positive correlation $\left(\mathrm{r}=0.623^{* *}\right)$ observed between days to germination and days to flowering and it was statistically significant. Days to flowering had weak and or negative correlation with most of the characters. Seedlings $/ \mathrm{m}^{2}$ exhibited strong positive correlation with days to flowering $\left(\mathrm{r}=0.752^{* *}\right)$ while it was strong but negative with plant weight $\left(r=-0.901^{* *}\right)$, \% flowering $(r=-0.940)$, harvested plants $(r=-0.946)$, marketable yield $t / h a(r=-0.943)$ and total fresh yield $t / h a(r=-0.942)$. Days to flowering had strong correlation with single plant weight $\left(r^{2}=0.868 * *\right)$, \% flowering $\left(r^{2}=-0.785^{* *}\right)$, number of plants harvested $\left(r=-0.701^{*}\right)$, marketable yield $\mathrm{t} / \mathrm{ha}(\mathrm{r}=-0.689 *)$ and total fresh yield $\mathrm{t} / \mathrm{ha}\left(\mathrm{r}=-0.686^{*}\right)$. Plant height, length and width of leaf, number of flower stalks and weight of flower stalk showed weak relationship with most the characters. Single plant weight exhibited strong but negative correlation with \% flowering $\left(\mathrm{r}=-0.945^{* *}\right)$, number of harvested plants $\left(\mathrm{r}=-0.910^{* *}\right)$ and marketable yield $\mathrm{t} / \mathrm{ha}\left(\mathrm{r}=-0.898^{* *}\right)$. Percentage of flowering had strong negative correlation with number of harvested plants $(\mathrm{r}=$ $\left.0.955^{* *}\right)$ and marketable yield $\mathrm{t} / \mathrm{ha}\left(\mathrm{r}=-0.954^{* *}\right)$. Number of harvested plants showed very strong and significantly positive correlation with marketable yield $\mathrm{t} / \mathrm{ha}\left(\mathrm{r}=0.999^{* *}\right)$. This result revealed the sources of variation in respect to yield and yield attributes which mostly depended on plant population which is influenced by seed quality or germination percentage of seeds. Seed quality might have varied due to collection time, storage variation, purity of seeds, and other factors. This result corroborates the reports of Mozumder et al. (2003) that all the races of Bangladhonia cultivated in Bangladesh might belong to the same species E. foetidum L. 
Table 3. Phenotypic correlations coefficient among different characters of Bangladhonia genotype.

\begin{tabular}{|c|c|c|c|c|c|c|c|c|c|c|c|c|c|}
\hline Traits & SM & DF & PHT & PW & LP & LL & WL & FS & $\% \mathrm{Fl}$ & WFS & HP & MYld & $\% \mathrm{DM}$ \\
\hline DTG & .312 & $.623 *$ & -.509 & -.428 & -.171 & -.304 & -.483 & -.068 & -.353 & -.320 & .229 & .219 & -.090 \\
\hline SM & & $\begin{array}{c}.752 * \\
*\end{array}$ & -.298 & - & -.214 & -.026 & -.616 & .161 & -.940 & -.108 & .946 & .943 & -.533 \\
\hline DF & & & -.364 & $\begin{array}{c}- \\
.868^{* *}\end{array}$ & -.192 & -.329 & -.528 & .159 & $-.785^{* *}$ & -.347 & $.701^{*}$ & $.689 *$ & -.529 \\
\hline PHT & & & & .335 & .177 & .488 & .077 & .220 & .200 & -.115 & -.246 & -.232 & .040 \\
\hline PW & & & & & .222 & .316 & $.650 *$ & -.078 & $.945 * *$ & .271 & $-.910 * *$ & $-.898 * *$ & .655 \\
\hline LP & & & & & & .318 & .004 &. & .343 & -.125 & -.288 & -.304 & .543 \\
\hline LL & & & & & & & -.153 & .083 & .120 & -.099 & -.122 & -.103 & .187 \\
\hline WL & & & & & & & & .075 & $.701^{*}$ & .283 & -.570 & -.567 & .447 \\
\hline FS & & & & & & & & & -.250 & .351 & .311 & .336 & -.109 \\
\hline$\% \mathrm{Fl}$ & & & & & & & & & & .143 & $-.955 * *$ & $-.954 * *$ & $.668 *$ \\
\hline WFS & & & & & & & & & & & .021 & .038 & .476 \\
\hline HP & & & & & & & & & & & & $.999 * *$ & -.516 \\
\hline MYld & & & & & & & & & & & & & -.513 \\
\hline
\end{tabular}

* Correlation is significant at the 0.05 level (2-tailed).

** Correlation is significant at the 0.01 level (2-tailed).

\begin{tabular}{|c|c|c|c|}
\hline \multirow[t]{14}{*}{ Legends, } & DTG & $=$ & Days to germination \\
\hline & $\mathrm{SM}$ & $=$ & Seedlings $/ \mathrm{m}^{2}$ \\
\hline & DF & $=$ & Days to flowering \\
\hline & PHT & $=$ & Plant ht. (cm) \\
\hline & PW & $=$ & Plant wt. (g) \\
\hline & LP & $=$ & Leaves /plant \\
\hline & LL & $=$ & Leaf length $(\mathrm{cm})$ \\
\hline & WL & $=$ & Leaf width $(\mathrm{cm})$ \\
\hline & FS & $=$ & Flower stalk $/ \mathrm{m}^{2}$ \\
\hline & $\% \mathrm{Fl}$ & $=$ & $\%$ flowering \\
\hline & WFS & $=$ & Flower stalk weight $\mathrm{g} / \mathrm{m}^{2}$ \\
\hline & $\mathrm{HP}$ & $=$ & Harvested plants $/ \mathrm{m}^{2}$ \\
\hline & MYld & $=$ & Marketable yield t/ha \\
\hline & $\% \mathrm{DM}$ & $=$ & $\%$ of dry matter \\
\hline
\end{tabular}

\section{Hierarchical cluster analysis}

Fig 1. Showed the Hierarchical cluster analysis using different yield attributing and other characters of 12 Bangladhonia genotypes. Here the Dendogram using single linkage showed two division or cluster of genotypes. Cluster one having 
11 genotypes which have minimum distances among them, while only one genotype represented the cluster two. The morphological features of the second cluster were same but yield performances were different which was mainly due to the number of plants harvested. The number of plants were closely related with the number of seeddlings $/ \mathrm{m}^{2}$ that was depended on the seed germination. The germination of BD012 was poor as a result less seedlings were grown and harvestable plants were minimum which caused lowest yield. So, it could be assumed that the yield variation of the genotype BD012 from other was not due to genetic factor because all other characteristics were similar in all genotype. The overall performance of collected 12 genotypes was similar and there are close relationship among them. Most of the phenotypic characters were same except some characters which were depended on seed germination. All the qualitative character showed similar performance which indicates less variation among the genotypes.

\section{Dendogram using single linkage}

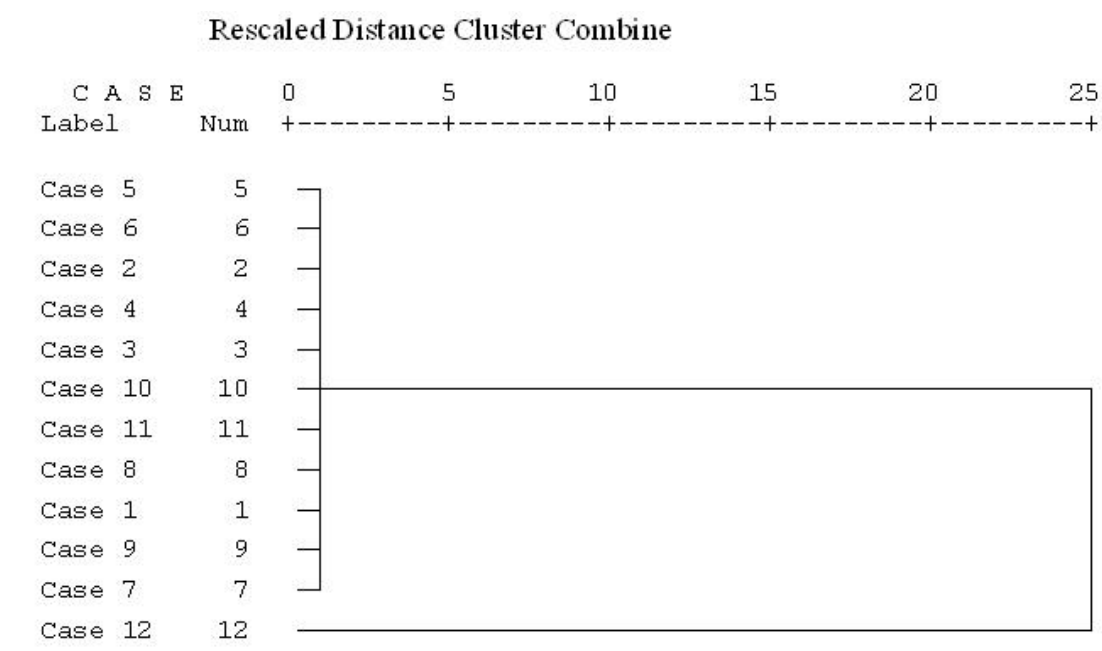

Fig 1. Dendogram using single linkage cluster of 12 Bangladhonia genotypes.

Most of the yield attributing characters and individual plant performances exhibited no differences among the genotypes. Only BD012 showed slight difference which might be due to lower plant population per plot. Considering the above result and discussion, it is possible to reach at the conclusion that all of the genotypes belong to the same species of Bangladhonia (E. foetidum L.) and there was no major phenotypic or genotypic variation among them. Hence, it may be concluded that all the genotypes belong to the same species with similar genetic make up. 


\section{References}

Adams, C. D. 1971. Flowering plants of Jamaica. Postharvest Biology and Technology, The Univ. of the West Indies. Mona, Jamaica, W.I. 7 (1-2): 109-118.

Anonymous. 1989. Annual Research Report (1988-1989), Bangladesh Agricultural Research Institute, Joydevpur, Bangladesh. P. 312.

Bendre, A. and P. C. Pande. 1999. Introductory Botany (4 ${ }^{\text {th }}$ ed.). Rastigo Pub, India. P. 697.

Islam, M. R., S. N. Mozumder, M. Moniruzzaman and S. N. Alam. 2003. Effects of N, P and $\mathrm{K}$ on yield and profitability of Bilatidhonia in the hilly region. Bangladesh $J$. Agril. Res. 28 (1):105-110.

Lawrence, G. H. M. 1967. Taxonomy of Vascular Plants. Oxford and IBH pub. Co. Calcutta. P. 646.

Moniruzzaman, M., S. M. M. Rahman and S. N. Mozumder. 2000. Effect of seed rate and shade on false coriander (Eryngium foetidum L.) production in the hilly area. Bangladesh Hort. 28(1\&2): 34-38.

Moniruzzaman, M., M. M. Hossain, T. Hossain and M. G. Miah. 2006. Response of Bangladhonia (Eryngium foetidum L.) to light intensity and nitrogen fertilization. $J$. Sci. Technol. (Dinajpur) 4: 27-36.

Mozumder, S. N. 2003. On farm investigation on Bilatidhonia cultivation and development of improved cultivation package. A survey report under NSICT. Ministry of Sci. \& Information and Communication Technol. Dhaka -1000. P-6.

Nienga, J. 1995. Production of Eryngium. North Carolina Flower Growers Bulletin. 40(4): 9-11.

Rashid, M. M. 1999. Shabjibigyan (In Bengali). Rashid Publishing House, 94, Old DOHS, Dhaka-1206. P. 504-505.

Rubatzky, V. E., C. F. Quiros and P. W. Simon. 1999. Carrots and Vegetable Umbelliferae. Crop production Science in Horticulture, series 10. CABI Pub., CAB Int., Wallingford, UK. P. 294. 